2016 Global Marketing Conference at Hong Kong Proceedings: 1073-1080 (July 2016) http://dx.doi.org/10.15444/GMC2016.07.09.05

\title{
CONSUMER RESPONSES TO PROMOTIONAL TOOLS IN HOTELS: A CASE STUDY OF CHINESE CONSUMERS
}

\author{
Jenny Weichen Ma, University of Greenwich, UK ${ }^{1)}$ \\ Marwa Gad Mohsen, University of Worcester, $\mathrm{UK}^{2)}$
}

\begin{abstract}
The rapid growth of the Chinese tourism has stimulated competition within tourismrelated industries, such as the hospitality industry. The purpose of this study is to examine the Chinese consumer reaction to different promotional tools used by hotels in China and, thus, to provide a deeper understanding for marketers of how to use sales promotion effectively to generate appropriate consumer responses. An experimental survey was administered yielding a total sample of 319 Chinese customers, who were probed using different types of sales promotion tools. Data analysis indicates that bonus packs (e.g. a 3-night stay at a hotel for the price of 2) induced the highest consumer perceived value, brand switching, and purchase acceleration intention, whereas price discounts resulted in the highest intention to spend more. Although this study has its limitations given its reliance on a convenience sample, it offers insightful practical implications for hotel business owners in Asia regarding targeting the right customers with the right promotional tools, where it is proposed that bonus packs successfully attract new Chinese customers and price discounts support in generating more sales.
\end{abstract}

Keywords: promotional tools, Chinese consumers, hotel industry

\section{INTRODUCTION}

Since the economic reforms in 1978, there has been a massive change in the Chinese consumer lifestyles due to increasing disposable incomes, which led the Chinese tourism industry to experience phenomenal development over the past three decades (Gu, Ryan, \& Yu, 2012). According to the local media, the Chinese hotel industry has recovered in 2014-15 after a 'cool down' in 2013, with growth realized in particular market segments 'due to oversupply and under-reporting of performance' (Chinatravelnews.com, 2015: Online). Another market report reviewing the exploding growth in China's hospitality industry forecasts that it will become a $\$ 100$ billion industry with 6.3 million rooms over the next decade, with ample room for growth and the emergence of new entrants (Atkearney.co.uk, 2013), since both domestic and international travellers are still on the rise. Moreover, it is estimated that China will be the world's No. 1 tourism destination and the fourth-largest nation of tourists by 2020 (China National tourist office, 2014). These projections suggest that competition within the hotel industry in China will become even fiercer. Given that hotel booking is the obvious main contributor to the profits of the hotel industry (Pan, 2007; Wang, Chen, \& Chen, 2012), means of successfully attracting

\footnotetext{
1) j.ma@worc.ac.uk

2) m.gadmohsen@worc.ac.uk
} 


\section{Global Marketing Conference at Hong Kong}

customers becomes a vital task for hospitality marketers, and a better understanding of the effective use of promotional tools can be beneficially invaluable in increasing market shares and sales.

Promotional tools have been extensively studied in marketing literature, however, many such studies focus on other industries such as the retail sector (e.g. Shi, Cheung, \& Prendergast, 2005; Mcneill, 2013) and other service sectors such as telecommunications (Okyere, Agyapong, \& Nyarku, 2011; Obasan \& Soyebo, 2012). There is a dearth of studies on the use of promotional tools in the hotel industry in particular. There is also a knowledge gap in that many studies have only investigated a specific promotional tool, such as price discounts (e.g. Alba, Mela, Shimp, \& Urbany, 1999; Blattberg \& Neslin, 1990); whilst these studies have contributed to a better understanding of a certain promotional technique, a comparison of different promotional tools can provide marketers with information in making decisions on the optimal promotional strategies to be employed.

For instance, there is a generic belief that price variations may be an effective promotional tool; however, an existing study argues that Chinese hotel customers are less likely to solely rely on price-related benefits in their choice of hotel stay (Kim \& Kim, 2006). Accordingly, the aim of the current study is to describe the impact on Chinese customers of employing differing promotional tools within the hotel business. The research objectives are not only to examine the consumer perceived value of various promotional tools in the hotel industry but also to determine whether specific types of promotional tools elicit specific consumer responses as opposed to others. This study contributes to literature on the effectiveness of sales promotion by investigating various promotional tools simultaneously to offer hotel marketers in China a better understanding of how to use them more effectively to stand out in such a competitive sector.

\section{THEORETICAL BACKGROUND}

Promotion is an essential element of a successfully tailored marketing mix programme, calling for the use of appropriate strategies and tactics by any business. In employing it to deliver information related to the product/service to consumers, to persuade and attract customers to purchase the firm's products/services, higher sales can be achieved as well as opportunities for future sales can be created (Blattberg and Neslin, 1990). The Chartered Institute of Marketing highlights that the significance of utilizing promotional tools is reflected in how advertising and sales promotions account for at least $25 \%$ of UK marketing budgets (as cited in Buil et al., 2013). However, scholars have argued for further research on the effectiveness of using different promotional tools in specific industries as more than $50 \%$ of promotional strategies have been considered unsuccessful (Ailawadi, Beauchamp, Donthu, Gauri, \& Shankar, 2009).

Traditionally, promotions can be grouped into two classifications: monetary promotions and non-monetary promotions. Some studies such as Buil, de Chernatony, \& Martínez (2013) argue that monetary promotions, such as price discounts and coupons, may have a negative influence on brand image and perceived quality as consumers may use price as an extrinsic cue to infer product quality. Interestingly, there is a tweak in the use of a monetary reward 'premiums'. According to DelVecchio, Henard, \& Freling (2006), postpromotion brand preference was found to be higher when the sales promotion used is a 


\section{Global Marketing Conference at Hong Kong}

coupon or premium; this is the case, for instance, when a premium offer is used whereby another product is obtainable at a discount with the purchase of the original product.

Alternatively, Chandon, Wansink and Laurent explain that non-monetary promotions such as free gifts, samples, and contests may offer hedonic benefits for customers, including entertainment or new experiences (as cited in Buil et al., 2013). Keller found that both types of promotional tools have been found to have a positive impact on the business, scholars have argued that sales promotions could result in decreased brand loyalty, increased brand switching, decreased quality perceptions and increased price sensitivity (as cited in DelVecchio et al., 2006). It implies that the use of sales promotion should be strategically-deliberated - i.e. different promotional tools should be used in relation to business objectives and situations, as the way customers may respond to promotional tools can vary. Therefore, a better understanding of customer likely responses to various sales promotions tools calls for more systematic study to avoid costly business mistakes.

In order to understand the ways in which promotional tools influence customer intentions in making hotel bookings, this study takes forward from previous studies carried out by Gilbert and Jackaria (2002), and Shi, Cheung, and Prendergast (2005), which investigated how customers from Hong Kong respond to sales promotional tools. Formerly, Shi et al. (2005) examined consumer behavioural responses to company promotional efforts such as brand switching, purchase acceleration, stockpiling, product trial, and unexpected spending. To apply these in the hotel business context, this study investigates consumer likelihood of switching to another hotel brand, purchase acceleration (hotel visit acceleration), and the consumer's increased expenditure (booking more nights in a visit). Moreover, this study examines consumer perceived value of the promotional tools in order to see its correlation to behavioural responses.

The promotional tools studied in the current research are generated from the extant literature and current hotel offers used in hotels in China, including both monetary and non-monetary promotional techniques. These comprise: price discounts, coupons, premiums, bonus packs and games. Games, although non-monetary, bring benefits such as the perceived value of the prize, perceived fun and interest for those who participate in game-based promotions (Ward \& Hill, 1991). These benefits are also recognised by hotel marketers; for instance, the InterContinental Hotels Group (IHG) was giving away 1,000 free nights at IHG hotels around the world, where customers wishing for a chance to win a free night were required to simply place 'a pin' in their dream destination on the map provided on the hotel website, along with submitting their basic personal details (IHG, 2014).

\section{METHOD}

This study uses a descriptive design and employs an experimental survey method in its data collection using convenience sampling. The researchers started by scanning the current promotional offers of hotels in China corresponding to each type of promotional tools (price discounts, coupons, premiums, bonus packs, and games) to use them as 


\section{Global Marketing Conference at Hong Kong}

probes for the research participants. After reviewing each promotional tool, participants were required to answer a set of questions which measured their perceived value of the promotional tools and their behavioural responses (brand switching; spending acceleration; extra spending).

The consumer perceived value was measured using seven items adopted and adapted from Chandon et al. (2000) and d'Astous and Jacob (2002) studies of sales promotion effectiveness. To measure consumer purchase intention, brand switching, purchase acceleration and extra spending, scales were adopted and adapted from Shi et al. (2005) and Obeid (2014) to indicate the respondents' actual responses relative to the five sales promotional tools under study. All questions were measured using a Likert scale (1=Strongly Disagree, 5=Strongly Agree). As the scales were originally in English, the back-translation method was used to translate the questionnaire and validate it in Chinese, and a pilot study was conducted on 16 participants to ensure the reliability and the validity of the study and its scales. The Cronbach's Alpha for all variables in this study was confirmed as above 0.7 (Nunnally, 1978). After eliminating unusable questionnaires, a final sample size of 319 was used in the analysis.

\section{RESULT AND ANALYSIS}

\section{Participants' Profile}

Among the 319 respondents, 54.9\% were females (175 respondents) and $45.1 \%$ were males (144 respondents). Most of the sample was aged in the 21-30 (48.3\%) and 31-40 age brackets (30.4\%), with $15 \%$ were $41-50$ and $4.4 \%$ were aged under 20 and $1.9 \%$ over 50s. In terms of income levels, $37 \%$ of respondents reported an annual family income level of 6000- 15000 RMB(approx. 600-1500GBP), with 33.2\% reporting income of 15,000-30,000 RMB (approx. 1500 - 3000GBP), and 15.4\% an income between 30,000100,000 RMB (3000- 10,000 GBP). The rest of $12.2 \%$ and $2.2 \%$ reported $2000-6000$ RMB(approx.. 200 - 600 GBP) and over 100, 000 RMB (approx. over 10,000) respectively. Regarding level of education, the majority of the respondents $(94 \%)$ reported that they obtained a college degree or above.

\section{Promotional Tools, Perceived Value and Behavioural Responses}

This study adopts Shi et al.'s (2005) analysis methods and uses one-way repeat ANOVA test to compare the consumer perceived value and behavioural responses under five different promotional tools. Analysis results indicate significant differences on consumer perceived value for the five sales promotional tools (Wilk's Lambda $\lambda=.461$, at $p<.05$, with a mean score of 29.09 for bonus packs; 28.61 for price discounts; 27.19 for premiums; 24.90 for coupons; and22.23 for games). Findings demonstrate that customers may have a higher perceived value of bonus packs and price discounts than of coupons, premiums, and games.

Results highlight significant differences on brand switching $(\lambda=.51, p<.05)$; the findings indicate that price bonus packs (mean $x=4.16)$ and discounts $(x=4.13)$ are significantly rated by customers when it comes to intention for switching brands as opposed to coupons $(x=3.51)$, premiums $(x=3.71)$ and games $(x=2.97)$. Games as promotional tools 


\section{Global Marketing Conference at Hong Kong}

were found to have the weakest effect on brand switching among the five promotional tools. As for purchase acceleration, the results reflect significant differences $(\lambda=.499$, $p<.05$ ) between the tools, with bonus packs (mean $x=4.10)$ and price discounts $(x=4.02)$ found to be highly rated by customers for their purchase acceleration than are coupons $(x=3.46)$, premiums $(x=3.74)$ and games (mean=2.95). Finally, analysis results demonstrate significant differences in intentions of extra spending in relation to the five promotional tools $(\lambda=.52, p<.05)$. Similarly, findings further indicate that intentions to spend more were triggered by price discounts $(m=4.19)$ and bonus packs $(x=4.18)$ as opposed to coupons $(x=3.64)$, premiums $(x=3.87)$ and games $(x=3.06)$.

\section{Promotional Tools and Consumer Motivations for Hotel Stay}

This study used One-way ANOVA test to examine whether Chinese consumers' motivations for hotel stays influence the ways in which they respond to promotional tools. For price discounts, motivations for hotel stays only had a significant difference on how consumers perceived the promotional value of marketing promotions $(p<.05)$; those who had business motivations for hotel stays had the highest mean for perceived value of price discount promotions (mean $x=29.13$ ), followed by visiting friends/family as the motivation for hotel stays $(x=29.0)$. For coupon promotions, the differences between various motivations were found to be significant on perceived value, brand switching, purchase acceleration, and extra spending $(p<.01)$.

Participants with business travel motivations scored highest for perceived value of promotional coupons $(x=25.62)$ and brand switching intentions due to the coupons $(x=3.60)$. Customers with leisure motivations have the highest mean score for spending acceleration ( $x=3.55)$, while those motivated by visiting friends/family have the highest scores for extra spending $(x=3.71)$. As for premiums and bonus packs as promotional tools, there are no significant differences between the various motivation groups $(p>.05)$. Finally, in using games as promotional tools, significant differences between groups were only found for purchase acceleration $(p<.05)$, with business motivations having the highest scores.

\section{DISCUSSION \& CONCLUSION}

The research firstly compared the effectiveness of the five sales promotion tools under investigation for consumer perceived value on the three behavioural intentions: brand switching, purchase acceleration, and spending more. Remarkably, price discounts were not found as the most effective promotional tool in this study; instead, bonus packs (stay 3 nights for the price of 2) was found to trigger higher perceived value and all behavioural responses. This finding is inconsistent with the study of Blattberg and Neslin (1990) who postulate that price discount is often the most appealing promotional tool for customers. On the other hand, researchers also argue that bonus packs generally have an additional value for customers and have a strong impact on customer purchase behaviours (Belch, Belch, Kerr, \& Powell, 2009).

In this study, the bonus pack offered hotel customers an extra night of stay at the regular price. Theoretically speaking, the monetary value of this promotion was not greater than the price discount offered and used in this study (50\% off). Yet, the way participants 


\section{Global Marketing Conference at Hong Kong}

rated bonus packs as a more valuable promotion implies that customers perceive the value of promotions not simply based on their monetary value, but on the value of the product/service gained. In other words, this case demonstrates that rather than pay less money, the value point for customers was perceived/measured by the number of nights of hotel stay attained (the product itself) as opposed to the monetary value saved. This finding thus corresponds with prior literature on consumer perceived value, where economic value (e.g. price) is only one component among others, and consumer purchase intentions are in many instances driven by other more abstract perceived value components (Bojanic, 1996).

Another theoretical finding of this study is that it demonstrates how consumer motivations for hotel stays should be considered when using promotional tools. Consumers travelling for business surprisingly reacted more positively to price discounts, coupons, and games as promotional tools within the context of this study. These findings indicate that, despite their likelihood to be paid for/reimbursed for their business travel expenses including hotel accommodation, business travellers are still value-seekers. Baum also suggests in another study that a high percentage of business travellers report price as an important attribute for their hotel choice (as cited in Callan and Kyndt, 2001). This study also shows that the use of coupons for sales promotion by hotel marketers requires more deliberate consideration when it comes to customer segmentation, given that consumer motivations varied significantly in relation to perceived value of promotional tools and for all behavioural responses. It is argued that sales promotional initiatives need to be planned and properly managed, so marketers should be clear about who the target customer is and what the most suitable sales promotion approach is for a specific sales promotion objective (as suggested also by Brassington and Pettitt, 2000). For instance, coupons may be more effective in eliciting purchase acceleration for leisure travellers.

The present study offers some empirical findings on how Chinese consumers respond to promotional tools used by hotel businesses. Yet, it is only a preliminary study and its results may not be generalizable given the common limitation associated with using convenience sampling. Another limitation of this study is the design of promotional tools in the experimental survey; there might be other promotional tools currently employed in the hotel industry that were not studied in this research. Nevertheless, the research extends valuable insights on the effective use of the right sales promotional tools with practical implications for marketers. Future research directives can verify these findings using more specific customer segmentation, such as focusing on the leisure travellers segment.

\section{REFERENCES}

Ailawadi, K.L., Beauchamp, J.P., Donthu, N., Gauri, D.K., \& Shankar, V. (2009). Communication and promotion decisions in retailing: a review and directions for future research. Journal of Retailing, 85, 1, 42-55.

Alba, J. W., Mela, C. F., Shimp, T. A., \& Urbany, J. E. (1999). The effect of discount frequency and depth on consumer price judgment. Journal of Consumer Research, 26(Sept.), 99-114. 


\section{Global Marketing Conference at Hong Kong}

AtKearney (2013). China's hospitality industry: Rooms for growth. Retrieved from: http://www.atkearney.co.uk/documents/10192/982632/Chinas_Hospitality_Industr y.pdf/72ed00fb-1cad-4798-a1a1-1552604bc72e

Belch, G.E., Belch, M.A., Kerr, G., \& Powell, I. (2009). Advertising \& promotion: an integrated marketing communication perspective. Sydney: McGraw Hill.

Blattberg, R. C., \& Neslin, S. A. (1990). Sales promotion: Concepts, methods, and strategies. Englewood Cliffs, NJ: Prentice Hall.

Bojanic, D. C. (1996). Consumer perceptions of price, value and satisfaction in the hotel industry: An exploratory study. Journal of Hospitality \& Leisure Marketing, 4(1), 5-22.

Brassington, F., \& Pettitt, S. (2000). Sales Promotion, Principles of Marketing, $2^{\text {nd }}$ ed. FT Prentice Hall, Harlow, 642-685.

Buil, I., de Chernatony, L., \& Martínez, E. (2013). Examining the role of advertising and sales promotions in brand equity creation. Journal of Business Research, 66(1), 115-122.

Callan, R. J., \& Kyndt, G. (2001). Business travellers' perception of service quality: a prefatory study of two European city centre hotels. International Journal of Tourism Research, 3(4), 313-323.

Chandon, P., Wansink, B., \& Laurent, G. (2000). A benefit congruency framework of sales promotion effectiveness. Journal of Marketing, 64 (4), 65-81.

China Travel News (2015, October 20). RevPAR in China's hotel industry grows only 1.4\% in first eight months of 2015. Retrieved from: http://www.chinatravelnews.com/article/96371

China National Tourist Office (2014) China in brief. Retrieved from: http://www.cnto.org.uk/China_in_Brief/

d'Astous, A., \& Jacob, I. (2002). Understanding consumer reactions to premium-based promotional offers. European Journal of Marketing, 36(11/12), 1270-1286.

DelVecchio, D., Henard, D. H., \& Freling, T. H. (2006). The effect of sales promotion on post-promotion brand preference: A meta-analysis. Journal of Retailing, 82(3), 203-213.

Gilbert, D.C. \& Jackaria, N. (2002). The efficacy of sales promotions in UK supermarkets: a consumer view. International Journal of Retail\& Distribution Management, 30(6), 315-322.

Gu, H., Ryan, C., \& Yu, L. (2012). The changing structure of the Chinese hotel industry: 1980-2012. Tourism Management Perspectives, 4, 56-63.

IHG Rewards Club (2014) Where would you go? Retrieved from: https://freenights.ihg.com/

Kim, W. G., Ma, X., \& Kim, D. J. (2006). Determinants of Chinese hotel customers'esatisfaction and purchase intentions. Tourism Management, 27(5), 890-900.

McNeill, L. (2013). Sales promotion in Asia: successful strategies for Singapore and Malaysia. Asia Pacific Journal of Marketing and Logistics, 25(1), 48-69.

Nunnally, J. (1978). Psychometric Methods. New York: McGraw Hill.

Obasan, K. A., \& Soyebo, Y. A. (2012). Assessing the effectiveness of promotion as a marketing management tool in the Nigerian telecommunication industry. Journal of Emerging Trends in Economics and Management Sciences, 3(1), 1-6. 
Okyere, N. Y. D., Agyapong, G. K., \& Nyarku, K. M. (2011). The effect of marketing communications on the sales performance of Ghana Telecom (Vodafone, Ghana). International Journal of Marketing Studies, 3(4), 50.

Pan, C. (2007) Market demand variations, room capacity, and optimal hotel room rates. International Journal of Hospitality Management ,26 (3), 748-753.

Shi, Y.Z., Cheung, K.M., \& Prendergast. G. (2005) Behavioural Response to Sales Promotion Tools - A Hong Kong Study, International Journal of Advertising, 24(4), 469-489

Wang, C. H., Chen, K. Y., \& Chen, S. C. (2012). Total quality management, market orientation and hotel performance: The moderating effects of external environmental factors. International Journal of Hospitality Management, 31(1), 119-129.

Ward, J. C., \& Hill, R. P. (1991). Designing effective promotional games: Opportunities and problems. Journal of Advertising, 20(3), 69-81. 